\title{
Research Article \\ Determinan rokok elektrik di Indonesia: data SUSENAS (Survei Sosial Ekonomi Nasional) tahun 2017
}

Electric cigarette determinants in Indonesia: using SUSENAS (National Social Economic Survey) data in 2017

Musliyah Syahrawani Elsa ${ }^{1}$, Mardiati Nadjib²

\section{Abstract}

\section{Dikirim:}

11 Januari 2019

Diterbitkan:

25 Februari 2019
Objective: Socio-economic disparity has been established to use conventional cigarettes, but the socio-economic picture of the use of e-cigarettes has not been well described. Therefore, this study aims to estimate the socio-economic determinants and behavior of conventional cigarettes on the use of e-cigarettes in Indonesia. Method: This study data uses SUSENAS (National Socio-Economic Survey) data with a cross sectional method collected in March 2017. To see the determinants of the use of e-cigarettes, this study conducted econometric analysis using LPM and Probit analysis. This analysis was carried out using STATA software version 14. Results: of all the independent variables in this study, which showed a significant relationship to the dependent variable (electric smoking) was age 25-45 years, gender, regional status, education, economic status in quintile 5 , and all categories of tobacco smoking status. The pseudo R2 results on the probit model show results of 0.2373 . Conclusion: Social economics is a factor associated with electric smoking behavior as well as smoking status. Age has a relationship with electrical smoking behavior where for Indonesia the age group that smokes electrically is dominated by adults (25-45) and parents (45$65)$. In addition, secondary education, higher education, and individuals who have economic status in quintile 5 have a significant relationship with the use of e-cigarettes. Factors that use tobacco cigarettes which are currently active smokers, who have quit smoking and who have never smoked, contribute to electric smoking behavior.

Keywords: electric cigarettes; determinants; SUSENAS

\footnotetext{
${ }^{1,2}$ Ekonomi Kesehatan, Universitas Indonesia
} 


\section{PENDAHULUAN}

Secara dunia, merokok merupakan salah satu faktor resiko yang memnyebabkan kematian dan disabilitas pada manusia serta diestimasikan akan membunuh 6 juta orang setiap tahunnya (1). Untuk mencegah penyakit dan kematian akibat rokok, peneliti memberikan beberapa alternatif seperti smokeless tobacco (ST) dan nicotine delivery systems yang salah satu cara dan paling popular adalah rokok elektrik (2). Rokok elektronik (e-rokok) adalah perangkat bertenaga baterai yang memberikan nikotin yang diuapkan, biasanya dalam propilen glikol atau gliserin (3). Studi yang dilakukan di 7 negara terdiri dari rusia, german, UK, Poland, France, Italy and South Korea menunjukkan peningkatan hampir dua kali lipat dari tahun 2013 sampai 2015 sebesar 0,9\% menjadi 1,7\% (4).

Rokok elektrik menjadi semakin popular akan tetapi produk ini tidak memberkan informasi secara detail tentang kandungan dalam rokok elektrik dan para produsen menklaim bahwa rokok elektrik lebih aman dibandingkan dengan rokok konvensional atau tembakau (5). Rokok elektrik memang memiliki bahaya yang lebih rendah dibandingkan rokok tembakau, akan tetapi rokok elektrik adalah jenis yang lebih berbahaya dibandingkan jenis inhaler nikotin lainnya dan tidak ada publikasi data yang menyatakan keamanan rokok elektrik (6). Bahkan WHO mempertanyakan keamanan dan efek dari rokok elektrik (7). Selain itu the Food and Drug Administration merilis temuan bahwa nikotin dan diethylene glycol ditemukan pada beberapa rokok elektrik yang mengiklankan sebagai nicotin-free $(2,6)$.

Untuk mengontrol penggunaan rokok elektrik, benerapa negara telah membuta kebijakan terkait rokok elektrik. Negara-negara tersebut seperti Australia, Brasil, Cina, Singapura, Thailand dan Uruguai telah sepenuhnya melarang penjualan dan pemasaran ENDS (2). Saat ini FDA (US Food and Drug Administration) sedang membangun standarstandar produk rokok elektrik dan kebiajkan tentang pembuatan, import, pengemasan, pelabelan, periklanan, marketing, penjualan dan distribusi rokok elektrik termasuk komponen dan bagian dari rokok elektrik (8). Di Indonesia, kebijakan terkait rokok elektrik yang telah ditetapkan adalah tentang peraturan impor rokok elektrik dan penetapan tarif cukai (9).

Studi menunjukkan bahwa status ekonomi dan pendidikan yang tinggi memiliki pengaruh dan berhubungan dengan jumlah pengguna rokok elektrik (10). Rokok elektrik mayoritas digunakan oleh laki-laki dibandingkan dengan perempuan (11-13). Selain itu, pertanyaan tentang manfaat rokok elektrik sebagai alat bantu berhenti merokok sebagian besar masih belum terjawab (14). Pada tahun 2015, sekitar 37\% dari pengguna rokok elektrik (meningkat 31\% dari tahun 2013) merupakan orang yang telah berhenti dari rokok konvensional (4). Penggunaan rokok elektrik dipegaruhi lebih besar oleh perokok aktif konvensional sebagai alternative dalam upaya untuk berhenti merokok (Verplaetse).

Kesenjangan social ekonomi telah ditetapkan untuk menggunaan rokok konvensional, akan tetapi gambaran social ekonomi terhadap penggunaan rokok elektrik belum tergambarkan dengan baik $(15,16)$. Oleh karena itu, studi ini bertujuan untuk mengestimasi determinan social ekonomi dan perilaku rokok konvensional terhadap penggunaan rokok elektrik di Indonesia.

\section{METODE}

Data studi ini menggunakan data SUSENAS (Survei Sosial Ekonomi Nasional) pada tahun 2017 yang memiliki informasi social dan ekonomi individu dan rumah tangga di Indonesia. Data ini diambil dengan menggunakan metode cross sectional pada bulan maret 2017. Informasi yang didapatkan dari SUSENAS dalam studi ini adalah umur responden, jenis kelamin, status merokok elektrik, status merokok konvensional, wilayah tempat tinggal. Sedangkan informasi rumah tangga yang digunakan dalam studi ini adalah pengeluaran per individu responden. Peneliti mengeluarkan responden yang beradah dibawah 15 tahun dan diatas 64 tahun karena distribusi perokok elektrik yang paling banyak hanya berada diantara umur tersebut. Selain itu peneliti hanya memasukkan responden yang menjawab variabel rokok elektrik dengan jawaban ya dan tidak (jawaban tidak tahu dan missing dikeluarkan). Hal tersebut memberikan sampel sebesar 703.388 observasi.

SUSENAS menyediakan informas perokok konvensional dalam 3 pilihan jawaban yang terdiri dari perokok elektrik setiap hari, perokok tidak setiap hari, tidak pernah merokok elektrik, dan tidak tahu. Sedangkan untuk informasi perokok konvensional (tembakau), data menyediakan dalam beberapa pertanyaan kemudian peneliti membagi dalam 3 variabel yang terdiri dari currentuse (perokok tembakau saat ini), pastuse (saat ini tidak merokok akan tetapi pernah merokok sebelumnya atau telah berhenti merokok tembakau), dan neveruse (tidak pernah merokok tembakau sama sekali).

Estimasi penggunaan rokokelektrik dapat dilihat berdasarkan faktor social ekonomi dan penggunaan rokok konvensionl. Model pada studi ini adalah, dependen variabel (Y), 1 jika responden responden merokok elektrik pada saat pengambilan data, dan 0 jika responden tidak merokok elektrik. Sedangkan independen variabel pada model studi ini adalah umur yang dikategorikan dalam 3 kelompok, umur-kuadrat, jenis kelamin, pendidikan, wilayah tempat tinggal (perkotaan atau pedesaan), tingkat pengeluaran, dan status perokok konvensional yang dikategorikan dalam current use, past use, dan never use. Untuk melihat determinan penggunaan rokok 
elektrik, studi ini melakukan analisis ekonometrik dengan menggunakan analisis LPM, dan Probit. Penggunaan ketiga analisis tersebut dikarenakan variabel dependen (penggunaan rokok elektrik) meruapakan variabel binary (1 dan 0) sehingga dapat melihat probabilitias responden yang merokok elektrik. Analisis ini dilakukan dengan menggunakan software STATA versi 14.

Peneliti hanya memasukkan variabel yang dapat eksogen. Umur memiliki hubugan dengan penggunaan rokok elektrik dibuktikan dengan penelitian (17), jenis kelamin (18), pendidikan $(19,20)$, status wilayah (21), tingkat pengeluaran $(21,22)$, dan status merokok konvensional atau tembakau $(23,24)$.

Variabel $y i$ merupakan variabel interest. $y i=1$ menunjukkan bahwa observasi $i$ sebagai karakteristik responden yang merokok elektrik dan yi=0 menunjukkan bahwa observasi $i$ sebagai karakteristik responden yang tidak merokok elektrik. Secara umum, model dari binary dependen variabel dapat didefinisikan sebagai berikut:

$$
E[y i \mid \mathrm{X} i]=\operatorname{Pr}(y i=1 \mid \mathrm{X} i)=F(\mathrm{X} i \circledast)
$$

Model diatas menjelaskan $E[$ ] mengindikasi ekspektasi nilai dan Pr ( ) merupakan probabilitas sedangkan F( ) mendefinisikan perbedaan spesifik model (variabel independen). Secara matematik, bentuk fungsi dalam studi ini sebagai berikut:

$P(Y=1 \mid X)=\beta_{0}+\beta_{1} X_{1}+\beta_{2} X_{4}+\beta_{3} X_{3}+\beta_{4} X_{4}+\beta_{5} X_{5} \ldots \ldots \ldots \ldots+u$

\section{HASIL}

Gambaran variabel yang digunakan dalam analisis ini dan hasil rangkuman statistiknya dapat dilihat pada tabel 1 . Terdapat 2,1\% responden yang merokok elektrik di Indonesia. Sekitar $47 \%$ dari sampel berumur antara 25-45 tahun, sebagiannya merupakan laki-laki, dan 54\% berpendidikan rendah. Selain itu, proporsi terbanyak dari pengeluaran responden adalah $20 \%$ pengeluaran teratas dan sekitar $68 \%$ tidak pernah merokok.

Berdasarkan hasil uji asumsi menunjukkan bahwa error term (uhat) tidak terdistribusi normal karena hasil Prob $>$ Z nya 0,000 $(<0,05)$. Akan tetapi, asumsi normalitas error term (uhat) tidak dapat dipertahankan untuk LPM karena variabel y (dependen variabel) gangguan uhat nya hanya terdiri dari 2 nilai yaitu (1 dan 0). Hasil uji multikolenariti yang mana standarnya bahwa jika vif menunjukkan bilangan lebih dari 10 maka terdapat kolenariti dalam model. Hasil uji model ini menunjukkan tidak terdapat kolenariti pada setiap variabel independen pada model ini. Studi ini melakukan uji endogenitas yang mana hasil model menunjukkan bahwa tidak terdapat endogenitas pada model tersebut sehingga model dapat diterima. Selanjutnya studi ini melakukan uji heteroscendasity yang mana hasilnya berdasarkan uji Breusch-Pagan dan White test, Prob>chi2 diperoleh
Tabel 1. Gambaran Variabel dalam Model Studi

\begin{tabular}{|c|c|c|c|}
\hline Variabel & Definisi & Mean & $\begin{array}{l}\text { Standar } \\
\text { Deviasi }\end{array}$ \\
\hline \multicolumn{4}{|c|}{ Variabel Dependen } \\
\hline $\begin{array}{l}\text { Merokok } \\
\text { Elektrik }\end{array}$ & $\begin{array}{l}1 \text { iresponden yang merokok } \\
\text { elektrik, o lainnya }\end{array}$ & 0.021 & 0,143 \\
\hline \multicolumn{4}{|c|}{ Variabel Independen } \\
\hline Age & Umur responden & & \\
\hline 15-24 tahun & $\begin{array}{l}1 \text { jika responden memiliki } \\
\text { umur } 15-24 \text { tahun, o lainnya }\end{array}$ & 0,241 & 0,428 \\
\hline 25-45 tahun & $\begin{array}{l}1 \text { jika responden memiliki } \\
\text { umur } 25-45 \text { tahun, o lainnya }\end{array}$ & 0,474 & 0,499 \\
\hline$>45$ tahun & $\begin{array}{l}1 \text { jika responden memiliki } \\
\text { umur }>45 \text { tahun, o lainnya }\end{array}$ & 0,305 & 0,460 \\
\hline Gender & 1 jika laki-laki, o perempuan & 0,503 & 0,499 \\
\hline $\begin{array}{l}\text { Status } \\
\text { Wilayah }\end{array}$ & $\begin{array}{l}1 \text { jika responden tinggal di } \\
\text { wilayah perkotaan, o lainnya }\end{array}$ & 0,453 & 0,498 \\
\hline \multicolumn{4}{|c|}{ Status Pendidikan } \\
\hline $\begin{array}{l}\text { Pendidikan } \\
\text { rendah }\end{array}$ & $\begin{array}{l}1 \text { jika pendidikan terakhir } \\
\text { responden SD atau tidak } \\
\text { sekolah, o lainnya }\end{array}$ & 0,545 & 0,498 \\
\hline $\begin{array}{l}\text { Pendidikan } \\
\text { menengah }\end{array}$ & $\begin{array}{l}1 \text { jika pendidikan terakhir } \\
\text { responden SMP-SMA, o } \\
\text { lainnya }\end{array}$ & 0,331 & 0,470 \\
\hline $\begin{array}{l}\text { Pendidikan } \\
\text { tinggi }\end{array}$ & $\begin{array}{l}1 \text { jika pendidikan terakhir } \\
\text { responden D1-S3,o lainnya }\end{array}$ & 0,123 & 0,329 \\
\hline \multicolumn{4}{|c|}{ Status Ekonomi } \\
\hline Kuintil 1 & $\begin{array}{l}1 \text { jika pengeluaran responden } \\
\text { berasa pada kuintil } 1(20 \% \\
\text { pengeluaran terendah), o } \\
\text { lainnya }\end{array}$ & 0,174 & 0,379 \\
\hline Kuintil 2 & $\begin{array}{l}1 \text { jika pengeluaran responden } \\
\text { berasa pada kuintil 2, } \mathrm{O} \\
\text { lainnya }\end{array}$ & 0,188 & 0,390 \\
\hline Kuintil 3 & $\begin{array}{l}1 \text { jika pengeluaran responden } \\
\text { berasa pada kuintil } 3,0 \\
\text { lainnya }\end{array}$ & 0,207 & 0,405 \\
\hline Kuintil 4 & $\begin{array}{l}1 \text { jika pengeluaran responden } \\
\text { berasa pada kuintil 4, O } \\
\text { lainnya }\end{array}$ & 0,218 & 0,413 \\
\hline Kuintil 5 & $\begin{array}{l}1 \text { jika pengeluaran responden } \\
\text { berasa pada kuintil } 5(20 \% \\
\text { pengeluaran tertinggi), O } \\
\text { lainnya }\end{array}$ & 0,213 & 0,409 \\
\hline \multicolumn{4}{|c|}{ Status Rokok Konvensional } \\
\hline current use & $\begin{array}{l}1 \text { jika responden merupakan } \\
\text { perokok konvensional saat } \\
\text { ini, o lainnya }\end{array}$ & 0,293 & 0,455 \\
\hline Past Use & $\begin{array}{l}1 \text { jika responden merupakan } \\
\text { perokok sebelumnya } \\
\text { kemudian berhenti saat ini, o } \\
\text { lainnya }\end{array}$ & 0,016 & 0,127 \\
\hline Never Use & $\begin{array}{l}1 \text { jika responden merupakan } \\
\text { tidak pernah merokok } \\
\text { konvensional, o lainnya }\end{array}$ & 0,689 & 0,463 \\
\hline
\end{tabular}

sebesar 0,000 yang menunjukkan bahwa hipotesis nul ditolak, artinya terdapat heteroscendasticity didalam model tersebut. Solusi untuk mengatasi masalah heteroscedasticity adalah dengan melakukan remedial measure (robust) pada model tersebut. Sebesar 72,54\% keseluruhan rate di dalam model dapat diklasifikasikan dengan benar, selain itu kemampuan covariat (X) dalam memprediksi Y(merokok elektrik) yang merokok elektrik sebesar 97,22\% (sensitivity), sendangkan kemampuan 
Tabel 2. Perbandingan Model Analisis LPM dan Probit

\begin{tabular}{|c|c|c|c|}
\hline \multirow{2}{*}{ Variabel } & \multirow{2}{*}{$\begin{array}{c}\text { LPM (OLS) } \\
\text { Koefisien } \\
(\text { Robust })\end{array}$} & \multicolumn{2}{|c|}{ Probit (MLE) } \\
\hline & & $\begin{array}{c}\text { Koefisien } \\
\text { (Robust) }\end{array}$ & $\begin{array}{c}\text { Marginal } \\
\text { Effect }\end{array}$ \\
\hline \multicolumn{4}{|c|}{$e^{\prime}$} \\
\hline \multicolumn{4}{|l|}{$>45$ tahun } \\
\hline \multirow[t]{2}{*}{ 15-25 tahun } & 0.000 & -0.006 & 0.000 \\
\hline & $(0.001)$ & $(0.020)$ & $(<0.000)$ \\
\hline \multirow[t]{2}{*}{$25-45$ tahun } & $0.003 * * *$ & $0.052^{* * * *}$ & $0.000^{*} *$ \\
\hline & $(0.001)$ & $(0.015)$ & $(<0.000)$ \\
\hline \multirow[t]{2}{*}{ Jenis Kelamin } & $0.002 * * *$ & $0.355^{* * * *}$ & $0.003^{* * * *}$ \\
\hline & $(0.000)$ & $(0.038)$ & $(<0.000)$ \\
\hline \multirow[t]{2}{*}{ Status Wliayah } & $0.007 * * * *$ & $0.160^{* * * *}$ & $0.002^{* * * *}$ \\
\hline & $(0.001)$ & $(0.013)$ & $(<0.000)$ \\
\hline \multicolumn{4}{|l|}{ Pendidikan } \\
\hline Pendidikan Rendah & --- & -- & \\
\hline \multirow[t]{2}{*}{ Pendidikan Menengah } & $0.002^{* * * *}$ & $0.030 * *$ & $<0.000^{* *} *$ \\
\hline & $(0.001)$ & $(0.014)$ & $(<0.000)$ \\
\hline \multirow[t]{2}{*}{ Pendidikan Tinggi } & $0.002^{*} *$ & $0.079^{* * * *}$ & $<0.000^{* * * *}$ \\
\hline & $(0.001)$ & $(0.023)$ & $(<0.000)$ \\
\hline \multicolumn{4}{|l|}{ Status Ekonomi } \\
\hline Kuintil 1 & -- & -- & \\
\hline \multirow[t]{2}{*}{ Kuintil 2} & -0.001 & -0.019 & $<-0.000$ \\
\hline & $(0.001)$ & $(0.022)$ & $(<0.000)$ \\
\hline \multirow[t]{2}{*}{ Kuintil 3} & 0.000 & 0.007 & $<0.000$ \\
\hline & $(0.001)$ & $(0.022)$ & $(<0.000)$ \\
\hline \multirow[t]{2}{*}{ Kuintil 4} & 0.001 & 0.034 & $<0.000$ \\
\hline & $(0.001)$ & $(0.022)$ & $(<0.000)$ \\
\hline \multirow[t]{2}{*}{ Kuintil 5} & $0.007 * * *$ & $0.155^{* * *}$ & $0.001 * * *$ \\
\hline & $(0.001)$ & $(0.023)$ & $<0.000$ \\
\hline \multicolumn{4}{|c|}{ Status Merokok Tembakau } \\
\hline current use & --- & --- & \\
\hline \multirow[t]{2}{*}{ Past Use } & $-0.067 * * *$ & $-0.910^{* * * *}$ & $-0.003^{*} * *$ \\
\hline & $(0.002)$ & $(0.054)$ & $(<0.000)$ \\
\hline \multirow[t]{2}{*}{ Never Use } & $-0.076^{* * * *}$ & $-1.585^{* * * *}$ & -0.054 **** \\
\hline & $(0.001)$ & $(0.033)$ & $(0.002)$ \\
\hline \multirow[t]{2}{*}{ Constant } & $0.069^{* * * *}$ & $-1.939^{* * * *}$ & \\
\hline & $(0.001)$ & $(0.043)$ & \\
\hline Observations & 703,388 & 703,388 & \\
\hline R-squared & 0.054 & & \\
\hline Pseudo $\mathrm{R}^{2}$ & & 0,2373 & \\
\hline Log Likelihood & & -63565659 & \\
\hline Prob $>\mathrm{Chi}^{2}$ & & 0,0000 & \\
\hline
\end{tabular}

Robust standard errors in parentheses

*** $\mathrm{p}<0.01,{ }^{* *} \mathrm{p}<0.05,{ }^{*} \mathrm{p}<0.1$

covariat (X) dalam memprediksi Y(merokok elektrik) yang tidak merokok elektrik sebesar 72,01\% (specificity). Dari hasil uji Hosmer-Lemeshow diketahui bahwa Prob>chi2 sebesar 0,1162, berdasarkan hasil tersebut dinyatakan bahwa $\mathrm{H}_{0}$ diterima, sehingga model diatas dapat menjelaskan variabel dependen (status merokok elektrik) (rokokelektrik).

Tabel diatas menjelaskan bahwa dari seluruh variabel independen pada studi ini, yang menunjukkan hubungan yang signifikan terhadap variabel dependen (merokok elektrik) adalah umur 25-45 tahun, jenis kelamin, status wilayah, pendidikan, status ekonomi pada kuintil 5, dan seluruh kategori status merokok tembakau. Hasil pseudo
R2 pada model probit menunjukkan hasil sebesar 0,2373.

Berdasarkan hasil uji LPM, persentasi variabel dependen yang dapat dijelaskan oleh model ini sebesar $5,3 \%$ sedangkan sisanya dapat dijelaskan oleh faktor lain yang tidak masuk dalam model yang diamati oleh peneliti. Responden yang berusia lebih dari 45 tahun akan lebih berpeluang merokok elektrik dibandingkan responden yang berusia 15-24 tahun sebesar 0,0007 setelah dikontrol variabel lainnya. Responden yang berumur antara 2445 tahun akan akan lebih berpeluang merokok elektrik sebesar 0,002 dibandingkan responden yang berusia lebih dari 45 tahun setelah dikontrol variabel lainnya. Responden dengan jenis kelamin laki-laki akan lebih berpeluang merokok elektrik sebesar 0,002 dibandingkan perempuan setelah dikontrol variabel lainnya.

Responden yang tinggal di wilayah perkotaan akan lebih berpeluang merokok elektrik sebesar 0,007 dibandingkan responden yang tinggal di pedesaan setelah dikontrol oleh variabel lainnya. Responden yang memiliki pendidikan menengah maupun tinggi akan lebih berpeluang merokok elektrik sebesar 0,002 dibandingkan dengan responden yang memiliki pendidikan rendah setelah dikontrol oleh variabel lainnya. Responden yang memiliki pada kuintil 5 akan lebih berpeluang merokok elektrik sebesar 0,007 dibandingkan dengan responden dengan pengeluaran pada kuintil 1 setelah dikontrol oleh variabel lainnya.

Responden yang current use (saat itu perokok rokok tembakau) akan lebih berpeluang merokok elektrik sebesar 0,067 dibandingkan dengan responden yang past use (saat itu telah berhenti merokok tembakau) sebesar 0,076 dibandingkan dengan responden yang never use (tidak pernah merokok tembakau) setelah dikontrol oleh variabel lainnya.

Ada banyak konsistensi di antara estimator dalam tingkat signifikansi koefisien. Seperti yang disarankan, membagi koefisien probit dengan 2.5, membuat hasil probit kira-kira sebanding dengan koefisien LPM. Untuk koefisien pada jenis kelamin, yang memberikan 0,142 $(=0,355 / 2,5)$ untuk probit, yang mana lebih besar dari koefisien LPM sebesar 0,002.

\section{BAHASAN}

Penelitian ini menunjukkan bahwa pengguna rokok elektrik di Indonesia lebih banyak digunakan oleh kelompok umur $>24$ tahun dibandingkan dengan usia remaja (15-24 tahun). Berbeda dengan beberapa jurnal sebelumnya yang menunjukkan bahwa penggunaan rokok elektrik didominasi oleh remaja (15-24 tahun) sebagai contoh penelitian yang dilakukan oleh Constantine yang menunjukkan bahwa rokok elektrik lebih digunakan oleh kelompok usia 15-39 tahun dibandingkan dengan orang yang lebih tua $(10,24)$. Berdasarkan studi yang dilakukan dijerman, mayoritas alasan kelompok usia remaja menggunakan rokok elektrik dikarenakan bahwa 
bahaya rokok elektrik lebih rendah dibandingkan rokok tembakau, kelompok usia dewasa dan tua mengatakan bahwa rokok elektrik sama bahayanya dengan rokok tembakau (25). Alasan lain oleh kelompok remaja dan muda adalah dikarenakan bentuk rokok elektrik yang unik, ragam rasa, dan penambahan energy menggunakan USB sehingga mudah digunakan (18). Berdeda dengan sebuah studi yang menyebutkan bahwa rokok elektrik merupakan cara dalam upaya berhenti mrokok tembakau (26).

Temuan studi ini menunjukkan bahwa pengguna rokok elektrik di Indonesia memiliki hubungan yang signifikan dengan jenis kelamin dimana probabilitas laki-laki lebih besar dibandingkan perempuan. Laki-Laki menggunakan rokok elektrik dengan tunjuan untuk mendapatkan kenikmatatan terhadap rasa, fasilitas social dan energy sedangkan perempuan mengatakan bahwa penggunaan rokok elektrik untuk mengendalikan berat badan (13). Studi lainnya yang dilakukan di komunitas rokok elektrik di Surabaya dan Semarang juga menunjukkan bahwa mayoritas perokok elektrik adalah laki-laki $(27,28)$. Begitupun di salah satu Sekolah Menengah Atas menunjukan laki-laki merupakan perokok elektrik terbanyak (29). Di Indonesia, probabilitas merokok elektrik paling besar oleh perokok yang tinggal di wilayah perkotaan dibandingkan dengan yang tinggal di wilayah pedesaan. Hal ini bertentangan dengan penemuan di amerika yang menunjukkan bahwa status wilayah tidak menunjukkan perbedaan sedangkan di Poland dan Eropa tingkat penggunaan rokok elektrik di wilayah perkotaan lebih besar dibandingkan dengan yang tinggal dipedesaan (11). Beberapa studi pun menemukan bahwa terdapat perbedaan antara pengguna rokok elektrik yang tinggal diwilayah perkotaan dan pedesaan (30).

Hasil studi ini menunjukkabn bahwa di Indonesia, pendidkan menengah dan pendidikan tinggi memiliki probabilitas yang lebih besar terhadap merokok elektrik dibandingkan dengan pendidikan rendah. Ketiga kelompok pendidikan menjelaskan bahwa mayoritas alasan penggunakan rokok elektrik adalah dikarenakan rokok elektrik sama bahayanya dengan rokok tembakau (25). Berbeda dengan studi yang dilakukan di Hawai mengindikasikan bahwa pendidikan tidak memiliki hubungan yang signifikan dengan penggunaan rokok elektrik. Beberapa studi di Indonesia pun menunjukkan bahwa mayoritas pengguna rokok elektrik adalah orang yang memiliki pendidikan tinggi $(27,28)$. Akan tetapi sebuah studi menjelaskan bahwa pendidikan dan pendapatan pengaruhnya terhadap rokok elekktrik tidak berhubungan secara statistic (15). Status ekonomi pada kuintil 5 (20\% pendapatan tertinggi) di Indonesia memiliki hubungan yang signifikan terhadap penggunaan rokok elektrik. Begitupun studi di Semarang yang menunjukkan sekitar 76,7\% perokok elektrik adalah orang yang memiliki pendapatan tinggi ( $\geq$ Rp. 2.000.000)
(27). Penggunaan rokok elektrik didominasi oleh perokok dengan pendapatan yang tinggi (14). Hal ini dikaitkan dengan paparan iklan pada social ekonomi tinggi yang lebih besar disbanding status ekonomi lainnya yang pada akhirnya berhubungan dengan peningkatan frekuensi pengguna rokok elektrik (10).

Studi ini menunjukkan bahwa di Indonesia current use memiliki probabilitas yang paling besar terhadap penggunaan rokok elektrik dibandingkan dengan past use dan never use. Secara umum, orang yang telah berhenti merokok tembakau menjadikan rokok elektrik sebagai alternative dari rokok tembakau atau berhenti merokok tembakau dan mayoritas dari mereka telah sukses dalam upaya berhenti merokok (3), akan tetapi perokok elektrik masih hawatir dengan potensi racun yang berhaya dari rokok tersebut (6). Studi di 2 kota di Indonesia juga menunjukkan hasil yang sama dimana mayoritas pengguna rokok elektrik adalah perokok aktif konvensional yang mana juga memberikan alasan bahwa penggunaan rokok elektrik sebagai alternatif untuk upaya berhenti merokok. Sebuah studi menyarankan bahwa rokok elektrik dapat menjadi alternative untuk mengurangi kebiasaan rokok tembakau $(27,18)$. Studi yang dilakukan di Britain menunjukkan bahwa perokok tembakau meyakini bahwa rokok elektrik memberikan ancaman yang lebih kecil terhadap kesehatannya dibandingkan rokok tembakau (31).

Studi yang dilkukan di 7 negara menunjukkan proporsi terbesar yang mengkonsumsi rokok elektrik adalah current use (perokok tembakau) dan proporsi terendah adalah never use (bukan perokok tembakau) (4). Akan tetapi,mayoritas perokok tembakau mengatakan bahwa penggunaan rokok elektrik dikarenakan rasa ingin tahu terhadap rokok elektrik diikuti dengan alasan sebagai cara untuk berhenti merokok tembakau. Sedangkan yang pernah merokok tembakau dan yang tidak pernah merokok juga menyatakan bahwa penggunaan rokok elektrik dikarenakan keingin tahuan terhadap rokok elektrik (25). Berbeda dengan studi di Kanada yang membuktikan bahwa alasan terbesar penggunaan rokok elektrik adalah untuk membantu berhenti dari rokok tembakau kemudian diikuti dengan rasa ingin tahu (Samantha shiplo). Hasil sistematik review mengenai efektifitas Nicotine Replacement Therapy (NRT) menemukan bahwa pengaruh rokok elektrik sebagai solusi mengatasi perilaku merokok tembakau hanya sebagai secondary outcome akan tetapi hasil metaanalisis membuktikan rokok elektrik berkontribusi dalam merduksi pengguna rokok tembakau dan merupakan intervens yang efektif (32).

Beberapa studi di Indonesia mengindikasikan penggunaan rokok elektrik terus meningkat dan cukup besar. Beberapa studi pun menjelaskan bahwa efektifitas rokok elektrik dalam mengatasi penggunaan rokok tembakau masih belum terbukti. Selain itu, analisis zat nikotin pun masih terdapat pada beberapa rokok 
elektrik yang mengatakan free-nicotin (2). Beberapa peraturan yang mengatur tentang rokok elektrik di Indonesia belum mencakup semua aspek dimana peraturan baru hal tentang aturan import rokok elektrik dan menetapkan biaya cukai sebesar 57\% (9). Di US, pemerintah menetapkan beberapa peraturan untuk mengontrol penggunaan rokok elektrik seperti peraturan tata cara marketing dan batal minimal penggunaan rokok elektrik (8). Studi ini menunjukkan bahwa pengguna rokok elektrik di Indonesia cukup besar maka dari itu. Oleh karena itu, pemerintah perlu melakukan kajian tentang produk rokok elektrik yang beredar di Indonesia serta melakukan analisis efektivitas rokok elektrik terhadap upaya berhenti merokok tembakau.

\section{SIMPULAN}

Sosial ekonomi menjadi faktor yang memiliki hubungan yang signifikan terhadap perilaku merokok elektrik begitupun status merokok tembakau. Umur memiliki hubungan dengan perilaku merokok elektrik dimana untuk Indonesia kelompok umur yang merokok elektrik didominasi oleh dewasa (25-45) dan orang tua (45-65). Jenis kelamin laki-laki lebih memiliki probabilitas yang lebih besar terhadap perilaku rokok elektrik dibadingkan perempuan dan individu yang bertempat tinggal di wilayah perkotaan memiliki probabilitas lebih besar dibandingkan dengan yang tinggal di pedesaan. Selain itu, pendidikan menengah, pendidikan tinggi, dan individu yang memiliki status ekonomi pada kuintil 5 berhubungan dengan penggunaan rokok elektrik. Faktor penggunaan rokok tembakau yang saat itu perokok aktif, yang telah berhenti merokok dan yang tidak pernah merokok pun berkontribusi dalam perilaku merokok elektrik. Studi ini masih menggunakan data cross sectional yang dilakukan pada satu waktu sehingga tidak mampu melihat probabilitas secara dinamis dalam kurun waktu tertentu. Oleh karena itu, disarankan menggunakan data panel agar mampu menjelaskan perubahan perilaku rokok elektrik di Indonesia. Kelemahan lain studi ini adalah tidak menganalisis secara dalam tentang perokok tembakau yang menggunakan rokok elektrik sebagai alternative upaya pemberhentian merokok. Selain itu, rekomendasi studi selanjutnya terkait rokok elektrik adalah perlu melakukan analisis dampak rokok elektrik terhadap kesehatan dan studi mendalam alasan faktor rokok tembakau terhadap rokok elektrik di Indonesia.

\begin{abstract}
Abstrak
Tujuan: Kesenjangan social ekonomi telah ditetapkan untuk menggunaan rokok konvensional, akan tetapi gambaran social ekonomi terhadap penggunaan rokok elektrik belum tergambarkan dengan baik. Oleh karena itu, studi ini bertujuan untuk mengestimasi determinan social ekonomi dan perilaku rokok konvensional terhadap penggunaan rokok elektrik di Indonesia. Metode: Data studi ini menggunakan data SUSENAS (Survei Sosial Ekonomi Nasional) dengan metode cross sectional yang dikumpulkan pada bulan maret tahun 2017. Untuk melihat determinan penggunaan rokok elektrik, studi ini melakukan analisis ekonometrik dengan menggunakan analisis LPM dan Probit. Analisis ini dilakukan dengan menggunakan software STATA versi 14. Hasil: dari seluruh variabel independen pada studi ini, yang menunjukkan hubungan yang signifikan terhadap variabel dependen (merokok elektrik) adalah umur 25-45 tahun, jenis kelamin, status wilayah, pendidikan, status ekonomi pada kuintil 5, dan seluruh kategori status merokok tembakau. Hasil pseudo R2 pada model probit menunjukkan hasil sebesar 0,2373. Simpulan: Sosial ekonomi menjadi faktor yang berhubungan dengan perilaku merokok elektrik begitupun status merokok tembakau. Umur memiliki hubungan dengan perilaku merokok elektrik dimana untuk Indonesia kelompok umur yang merokok elektrik didominasi oleh dewasa (25-45) dan orang tua (45-65). Selain itu, pendidikan menengah, pendidikan tinggi, dan individu yang memiliki status ekonomi pada kuintil 5 memiliki hubungan yang signifikan dengan penggunaan rokok elektrik. Faktor penggunaan rokok tembakau yang saat itu perokok aktif, yang telah berhenti merokok dan yang tidak pernah merokok pun berkontribusi dalam perilaku merokok elektrik.
\end{abstract}

Kata Kunci: rokok elektrik; determinan; SUSENAS 


\section{PUSTAKA}

1. Brown J, Beard E, Kotz D, Michie S, West R. Realworld effectiveness of e-cigarettes when used to aid smoking cessation: a cross-sectional population study. Addiction . 2014;109(9): 1531-1540.

2. Cho JH, Shin E, Moon S-S. Electronic-Cigarette Smoking Experience Among Adolescents. [Online] Journal of Adolescent Health. 2011. p. 542-546. Available from: doi:10.1016/j.jadohealth.2011.08.001

3. Goniewicz ML, Lingas EO, Hajek P. Patterns of electronic cigarette use and user beliefs about their safety and benefits: an internet survey. Drug and alcohol review. 2013;32(2): 133-140.

4. LLP. ,Y, Ernst. E-cigarette: an emerging category. 2016.

5. Cheng T. Chemical evaluation of electronic cigarettes. Tobacco control. 2014;23 Suppl 2: ii11-ii17.

6. Etter J-F. Electronic cigarettes: a survey of users. [Online] BMC Public Health. 2010. Available from: doi:10.1186/1471-2458-10-231

7. WHO. Marketers of electronic cigarettes should halt unproved therapy claims. [Online] WHO, 2011. Available from: https://www.who.int/mediacentre/ news/releases/2008/pr34/en/

8. Truth Initiative. E-CIGARETTES tobacco product. 2018; 1-19.

9. Kementerian Keuangan. Peraturan Menteri Keuangan Republik Indonesia No. 146/PMK.010/2017 tentang Tarif Cukai Tembakau. [Online] 2017. Available from: http://www.jdih.kemenkeu.go.id/fullText/2017/146 P MK.010 2017Per.pdf

10. Simon P, Camenga DR, Morean ME, Kong G, Bold KW, Cavallo DA, et al. Socioeconomic status and adolescent e-cigarette use: The mediating role of e-cigarette advertisement exposure. Preventive medicine. 2018;112: 193-198.

11. Hartwell G, Thomas S, Egan M, Gilmore A, Petticrew M. E-cigarettes and equity: a systematic review of differences in awareness and use between sociodemographic groups. Tobacco control. 2017;26(e2): e85-e91.

12. Littlefield AK, Gottlieb JC, Cohen LM, Trotter DRM. Electronic Cigarette Use Among College Students: Links to Gender, Race/Ethnicity, Smoking, and Heavy Drinking. [Online] Journal of American College Health. 2015. p. 523-529. Available from: doi:10.108 0/07448481.2015.1043130

13. Piñeiro B, Correa JB, Simmons VN, Harrell PT, Menzie NS, Unrod M, et al. Gender differences in use and expectancies of e-cigarettes: Online survey results. Addictive behaviors. 2016;52: 91-97.

14. Pokhrel P, Little MA, Fagan P, Kawamoto CT, Herzog TA. Correlates of use of electronic cigarettes versus nicotine replacement therapy for help with smoking cessation. Addictive behaviors. 2014;39(12): 18691873.

15. Friedman AS, Horn SJL. Socioeconomic Disparities in Electronic Cigarette Use and Transitions from Smoking. Nicotine \& tobacco research: official journal of the Society for Research on Nicotine and Tobacco. [Online] 2018; Available from: doi:10.1093/ntr/nty120

16. Hiscock R, Arnott D, Dockrell M, Ross L, McEwen A. Stop Smoking Practitioners' understanding of e-cigarettes' use and efficacy with particular reference to vapers' socioeconomic status. [Online] Journal of Smoking Cessation. 2019. p. 21-31. Available from: doi:10.1017/jsc.2018.9

17. Laverty AA, Filippidis FT, Vardavas CI. Patterns, trends and determinants of e-cigarette use in 28 European Union Member States 2014-2017. [Online] Preventive Medicine. 2018. p. 13-18. Available from: doi:10.1016/j.ypmed.2018.08.028

18. Lee H-Y, Lin H-C, Seo D-C, Lohrmann DK. Determinants associated with E-cigarette adoption and use intention among college students. Addictive behaviors. 2017;65: 102-110.

19. Hedman L, Backman H, Stridsman C, Bosson JA, Lundbäck M, Lindberg A, et al. Association of Electronic Cigarette Use With Smoking Habits, Demographic Factors, and Respiratory Symptoms. JAMA network open. 2018;1(3): e180789.

20. Ruokolainen O, Ollila H, Karjalainen K. Determinants of electronic cigarette use among Finnish adults. [Online] Nordic Studies on Alcohol and Drugs. 2017. p. 471-480. Available from: doi:10.1177/1455072517736618

21. Pérez A, Morello P, Braun S, Thrasher J, Mejía R. Family and school socioeconomic status as predictors of tobacco and e-cigarette use in adolescents: a study from a perspective of material, human, and social capital. [Online] Tobacco Induced Diseases. 2018. Available from: doi:10.18332/tid/84237

22. Romijnders K, Beijaert M, van Osch L, de Vries H, Talhout R. Tobacco cigarette use versus electronic cigarette use: determinants of smoking and vaping behavior. [Online] Tobacco Induced Diseases. 2018. Available from: doi:10.18332/tid/84216

23. Kinouani S, Castéra P, Laporte C, Pétrègne F, Gay B. Factors and motivations associated with use of e-cigarette among primary care patients in a prospective cohort study:e-TAC study protocol. [Online] BMJ Open. 2016. p. e011488. Available from: doi:10.1136/bmjopen-2016-011488

24. Vardavas CI, Filippidis FT, Agaku IT. Determinants and prevalence of e-cigarette use throughout the European Union: a secondary analysis of 26566 youth and adults from 27 Countries. Tobacco control. 2015;24(5): 442-448.

25. Eichler M, Blettner M, Singer S. The Use of E-Cigarettes. Deutsches Arzteblatt international. 2016;113(50): 847-854. 
26. Shiplo S, Czoli CD, Hammond D. E-cigarette use in Canada: prevalence and patterns of use in a regulated market. [Online] BMJ Open. 2015. p. e007971. Available from: doi:10.1136/bmjopen-2015-007971

27. Istiqomah., D.R: Cahyo., K, Indraswari. R. Gaya Hidup Komunitas Semarang Vaper Corner. Jurnal Kesehatan Masyarakat. 2016;4(2): 1-10.

28. Damayanti. A. Penggunaan Rokok Elektrik di Komunitas Personal Vaporizer Surabaya. 2016; Available from: doi:10.20473/jbe.v4i2.2016.250-261

29. Putra. GNE, Putra. MR, Prayoga. DGA, Astuti. PAS. Gambaran Pemahaman, Persepsi, dan Penggunaan Rokok Elektrik pada Siswa Sekolah Menengah Keatas di Kota Denpasar. Universitas Udayana. 2017; Available from: https://www.researchgate.net/ publication/322757539
30. Mumford EA, Stillman FA, Tanenbaum E, Doogan NJ, Roberts ME, Wewers ME, et al. Regional Rural-Urban Differences in E-Cigarette Use and Reasons for Use in the United States. The Journal of rural health: official journal of the American Rural Health Association and the National Rural Health Care Association. [Online] 2018; Available from: doi:10.1111/jrh.12333

31. Dockrell M, Morrison R, Bauld L, McNeill A. E-cigarettes: prevalence and attitudes in Great Britain. Nicotine \& tobacco research: official journal of the Society for Research on Nicotine and Tobacco. 2013;15(10): 1737-1744.

32. Wang D, Connock M, Barton P, Fry-Smith A, Aveyard P, Moore D. 'Cut down to quit' with nicotine replacement therapies in smoking cessation: a systematic review of effectiveness and economic analysis. [Online] Health Technology Assessment. 2008. Available from: doi:10.3310/hta12020 